\title{
PENERAPAN MODEL PEMBELAJARAN KOOPERATIF TIPE STUDENT TEAM ACHIEVEMENT DIVISIONS (STAD) UNTUK MENINGKATKAN HASIL BELAJAR MATEMATIKA SISWA KELAS VI SD NO. 1 SADING KECAMATAN MENGWI KABUPATEN BADUNG SEMESTER I TAHUN PELAJARAN 2016/2017
}

\author{
Ni Luh Gede Eka Indrawati ${ }^{1}$, Ndara T Renda ${ }^{2}$ \\ 1,2Jurusan PGSD, FIP \\ Universitas Pendidikan Ganesha \\ Singaraja, Indonesia \\ e-mail: ekaindrawati11@yahoo.com¹, ndararenda@yahoo.com²
}

\begin{abstract}
Abstrak
Penelitian ini bertujuan untuk mengetahui peningkatan hasil belajar matematika siswa setelah penerapan model pembelajaran kooperatif tipe Student Team Achievement Divisions (STAD). Penelitian ini merupakan penelitian tindakan kelas (PTK) yang dilaksanakan dalam dua siklus. Subjek penelitian adalah siswa kelas VI SD No. 1 Sading semester 1 tahun pelajaran 2016/2017. Objek penelitian adalah hasil belajar matematika. Data hasil belajar matematika siswa dikumpulkan dengan menggunakan tes hasil belajar. Selanjutnya data-data yang telah dikumpulkan dianalisis secara deskriptif kuantitatif. Hasil penelitian ini menunjukkan bahwa setelah diterapkan model pembelajaran kooperatif tipe Student Team Achievement Divisions (STAD) pada siklus I terjadi peningkatan hasil belajar matematika dari refleksi awal, yaitu 61,9 menjadi 73,9, pada siklus II mengalami peningkatan menjadi 83,2 pada siklus II. Berdasarkan hasil penelitian tersebut, dapat disimpulkan bahwa penerapan model pembelajaran kooperatif tipe Student Team Achievement Divisions (STAD) dapat meningkatkan hasil belajar matematika siswa kelas VI SD No.1 Sading Semester 1 Tahun Pelajaran 2016/2017.
\end{abstract}

Kata kunci: hasil belajar matematika, model pembelajaran kooperatif tipe STAD

\begin{abstract}
The purpose of the research is to know how to improve the student achievement in mathematic after using the cooperative learning type Student Team Achievement Divisions (STAD). The research is the present classroom action which two cycles the subject of th research is the student in VI grade of SD No. 1 Sading in the first semester in academic year 2016/2017. The object of the research is the achievement in mathematic. The result of the data analysis in mathematic was collected by examiration from the result of learning and then the data was cillected and analysis by descriptive kuantitative. The result of the research showed thatafter used the cooperative learning in type Student Team Achievement Divisions (STAD). In cycle I figured out the incresing the study result of mathematic from reflection first is 61,9 to 73,9 and in cycle I. Figured out the increasing to 83,2 in cycle II. Base on that result, would be concluded The model cooperatif learning type Student Team Achievement Divisions (STAD) can improve the mathematic result in VI grade of SD No. 1 Sading in semester I in academic year 2016/2017.
\end{abstract}

Keywords : learning outcomes of mathematic, cooperative learning type STAD 


\section{PENDAHULUAN}

Kemajuan teknologi pada saat ini tidak lepas dari peran pendidikan, dan pendidikan merupakan bagian hakiki dari kehidupan masyarakat. Oleh karena itu, masalah pendidikan merupakan tanggung jawab bersama antara keluarga, masyarakat dan pemerintah. Upaya meningkatkan mutu hasil belajar peserta didik disetiap tingkat pendidikan perlu diwujudkan agar memperoleh sumber daya manusia Indonesia yang dapat menunjang pembangunan nasional (UU No. 20 tahun 2003).

Pendidikan mempunyai arti yang sangat penting dalam kehidupan seharihari, baik dalam kehidupan individual, bermasyarakat, bangsa dan negara. Sebab itu, pendidikan harus dilaksanakan dengan sebaik-baiknya agar tercapai tujuan pendidikan yaitu mencerdaskan kehidupan bangsa dan mengembangkan manusia Indonesia seutuhnya, manusia yang beriman dan bertaqwa terhadap Tuhan Yang Maha Esa dan berbudi pekerti luhur, memiliki pengetahuan dan keterampilan, kesehatan jasmani dan rohani, kepribadian yang mantap dan mandiri serta rasa tanggung jawab kemasyarakatan dan kebangsaan.

Undang-undang Nomor 20 Tahun 2003 tentang Sistem Pendidikan Nasional menyebutkan bahwa pendidikan nasional berfungsi mengembangkan kemampuan dan membentuk watak serta peradaban bangsa yang bermartabat dalam rangka mencerdaskan kehidupan bangsa. Pendidikan nasional bertujuan untuk mengembangkan potensi siswa agar menjadi manusia yang beriman dan bertaqwa kepada Tuhan Yang Maha Esa, berahlak mulia, sehat, berilmu, cakap, kreatif, mandiri dan menjadi warga negara yang demokratis serta bertanggung jawab.

Trianto (2009), mengemukakan bahwa pendidikan adalah salah satu bentuk perwujudan kebudayaan manusia yang dinamis dan sarat perkembangan. Oleh karena itu, perubahan atau perkembangan pendidikan adalah hal yang memang seharusnya terjadi sejalan dengan perubahan budaya kehidupan. Perubahan dalam arti perbaikan pendidikan pada semua tingkat jenjang pendidikan perlu terus menerus dilakukan sebagai antisipasi kepentingan masa depan. Pendidikan yang mampu mendukung pembangunan di masa mendatang adalah pendidikan yang mampu mengembangkan potensi siswa, sehingga yang bersangkutan mampu menghadapi dan memecahkan problema kehidupan yang dihadapinnya. Pendidikan harus menyentuh potensi nurani maupun potensi kompetensi siswa. Hasil pendidikan tersebut terasa semakin penting ketika seseorang harus memasuki kehidupan di masyarakat dan dunia kerja karena yang bersangkutan harus mampu menerapkan apa yang dipelajari di sekolah untuk menghadapi problema yang dihadapi dalam kehidupan sehari-hari saat ini maupun yang akan datang.

Matematika merupakan salah satu bidang studi yang menduduki peranan penting dalam pendidikan dan kehidupan masyarakat. Matematika merupakan salah satu pengetahuan tertua dan dianggap sebagai induk atau alat dan bahasa dasar banyak ilmu. Karena itu setiap siswa perlu memiliki penguasaan matematika pada tingkat tertentu. Pembelajaran matematika berkenaan dengan ide-ide, strukturstruktur, dan hubungan-hubungannya yang diatur menurut urutan yang logis (Soedjadi, 2008). Selain itu, dengan mempelajari matematika diharapkan siswa dapat memecahkan berbagai persoalan yang dihadapi, baik masalah yang berkaitan dengan pelajaran matematika itu sendiri maupun yang berkaitan dengan kehidupan sehari-hari. Matematika juga sebagai salah satu ilmu eksak yang mempunyai objek yang abstrak yang pada umumnya menyebabkan siswa mengalami kesulitan dalam memecahkan masalah matematika. Objek-objek kajian matematika yang bersifat abstrak memerlukan pemikiran kritis dalam mengkaji konsep-konsep yang dikandungnya. Walaupun pengajaran matematika dilakukan dengan memperhatikan urutan konsep dan dimulai dari hal-hal yang sederhana atau gampang, ke hal-hal yang rumit atau sulit, yang menyebabkan pembelajaran matematika menjadi mudah, menyenangkan dan bermakna. Namun masih banyak pandangan siswa bahwa matematika adalah suatu pelajaran yang sulit dipahami dan menakutkan.

Dalam rangka meningkatkan hasil belajar siswa, guru mempunyai peranan yang penting. Permendiknas Nomor 16 
Tahun 2007 tentang Standar Kualifikasi Akademik dan Kompetensi Guru mengamanatkan bahwa kompetensi guru dikembangkan secara utuh yang terdiri dari empat kompetensi utama yaitu kompetensi pedagogik, kompetensi profesional, kompetensi sosial dan kompetensi kepribadian. Dalam kompetensi profesional, guru dituntut untuk selalu mengembangkan keprofesionalan secara berkelanjutan dengan melakukan tindakan reflektif. Sebagai tindakan nyata untuk meningkatkan keprofesionalan guru dapat dilakukan dengan: 1) melakukan refleksi terhadap kinerja sendiri secara terus menerus, 2) memanfaatkan hasil refleksi dalam rangka meningkatkan keprofesionalan, 3) melakukan penelitian tindakan kelas dan 4) mengikuti perkembangan jaman dengan belajar dari berbagai sumber (Permendiknas No. 16 Tahun 2007). Dengan harapan bahwa akan berakibat pada pelaksanaan pembelajaran berkualitas yang dapat dibuktikan dengan peningkatan hasil belajar siswa, khususnya pada mata pelajaran matematika.

Berdasarkan pengamatan sebagai salah satu guru pengasuh mata pelajaran matematika dan studi dokumen yang berkaitan dengan mata pelajaran matematika pada tanggal 4 Oktober 2016 pada kelas VI SD No. 1 Sading, Kecamatan Mengwi, Kabupaten Badung, diperoleh data nilai rata-rata kelas pada pelaksanaan TTS sebesar 61,9. Sedangkan Kriteria Ketuntasan Minimal (KKM) yang ditetapkan oleh sekolah sebesar 75. Berdasarkan hasil observasi pada saat pelaksanaan pembelajaran matematika nampak beberapa faktor yang mempengaruhi rendahnya hasil belajar mata pelajaran matematika yaitu: 1) pembelajaran masih berpusat pada guru dan komunikasi yang terjadi masih satu arah yaitu dari guru kepada siswa; 2) Dalam proses pembelajaran guru sulit untuk melibatkan siswa dalam pembelajaran sehingga kurang adanya interaksi antara siswa dengan guru, guru dengan siswa, maupun siswa dengan siswa; 3) Pendekatan yang digunakan bersifat monoton dan kurang bervariasi sehingga menyebabkan siswa cepat bosan.
Untuk mengatasi masalah rendahnya hasil belajar siswa pada mata pelajaran matematika diperlukan suatu solusi yang tepat, salah satu solusi yang dapat digunakan adalah menggunakan model pembelajaran kooperatif tipe Student Team Achievement Divisions (STAD). Pembelajaran kooperatif. model pembelajaran kooperatif merupakan teknik-teknik kelas praktis yang dapat digunakan guru setiap hari untuk membantu siswanya belajar setiap mata pelajaran, mulai dari keterampilam dasar sampai pemecahan masalah yang kompleks. Pembelajaran kooperatif siswa bekerja sama dalam kelompok kecil saling membantu untuk mempelajari suatu materi (Slavin, 2008; Santyasa, 2007; Ibrahim, 2000; Suprijono, 2009). Kelompok tersebut beranggotakan siswa dengan hasil belajar tinggi, rata-rata, dan rendah, laki-laki dan perempuan, siswa dengan latar belakang suku berbeda yang ada dikelas, kelompok heterogen ini bekerja sama dengan baik sebagai sebuah tim (Nur, 2005; Slavin, 2008; Nurhadi, dkk. 2004; Kuntjojo, 2009). Model STAD merupakan salah satu tipe dari model pembelajaran kooperatif. Model pembelajaran ini memiliki keunggulan yaitu terdapat skor kemajuan individu dan pengakuan terhadap prestasi tim (Rusman, 2012; Adesanjaya, 2011; Isjoni, 2012). Model pembelajaran koperatif tipe STAD merupakan pendekatan cooperative learning yang menekankan pada aktivitas dan interaksi diantara siswa untuk saling memotivasi dan saling membantu dalam menguasai materi pelajaran guna mencapai prestasi yang maksimal (Nurhadi, dkk., 2004; Slavin, 2008; Taniredja, 2011) Disamping itu, siswa dimungkinkan mengungkap ide atau pendapatnya dalam diskusi kelompok sehingga siswa akan terlibat aktif dalam pembelajaran dan diharapkan suasana belajar akan lebih bermakna. Untuk keperluan inilah pembelajaran kooperatf tipe STAD diterapkan untuk mengelompokkan kemampuan yang berbeda sehingga memungkinkan terjadinya interaksi antara guru dengan siswa serta antara siswa dengan siswa secara aktif sehingga diharapkan siswa yang pandai akan membantu siswa yang kurang pandai karena dalam STAD siswa harus mempunyai tanggung jawab secara 
individu dan secara kelompok sehingga akan memperbaiki kualitas pembelajaran dan meningkatkan hasil belajarnya.

Berdasarkan uraian di atas maka penting untuk dilaksanakan Penelitian Tindakan Kelas (PTK) dengan judul "Penerapan Model Pembelajaran Kooperatif Tipe Student Team Achievement Divisions (STAD) Untuk Meningkatkan Hasil Belajar Matematika Siswa Kelas VI SD No. 1 Sading Kecamatan Mengwi, Kabupaten Badung Semester I Tahun Pelajaran 2016/2017"

\section{METODE}

Jenis penelitian ini merupakan Penelitian Tindakan Kelas (PTK) atau Classroom Action Research. Penelitian tindakan kelas adalah penelitian kualitatif yang dilakukan oleh guru sendiri ketika mendapatkan permasalahan dalam pembelajaran dan mencarikan solusinya dalam upaya memperbaiki kualitas pembelajarannya (Trianto, 2011; Arikunto, 2016). Penelitian tindakan kelas (PTK) merupakan bagian dari penelitian tindakan yang dilakukan oleh guru di kelas, yang bertujuan memperbaiki dan meningkatkan proses pembelajaran di kelas melalui suatu tindakan bermakna.

Penelitian ini dilaksanakan di SD No 1 Sading, kecamatan mengwi, Kabupaten Badung. Waktu penelitian ini dilaksanakan pada rentang waktu semester 1 tahun pelajaran 2016/2017.

Subjek dalam penelitian ini adalah siswa kelas VI SD No 1 Sading semester 1 tahun pelajaran 2016/2017 yang berjumlah 39 siswa, yang terdiri dari 20 laki-laki dan 19 perempuan. Adapun objek dalam penelitian tindakan kelas ini adalah hasil belajar matematika siswa kelas VI SD No 1 Sading semester 1 tahun pelajaran 2016/2017 dengan model pembelajaran Student Team Achievement Divisions (STAD).

Penelitian ini dilakukan dalam 2 siklus. Masing-masing siklus terdiri dari empat tahap yaitu: 1) perencanaan, 2) pelaksanaan tindakan,

pengamatan/observasi, dan 4) refleksi.

Perencanaan, pada tahap ini mencangkup kegiatan yang dilakukan dalam rangka mempersiapkan perangkatperangkat pembelajaran. Kegiatankegiatan tersebut adalah sebagai berikut.
Menentukan materi atau pokok bahasan yang akan dibahas, c) Menyiapkan skenario (rancangan) pembelajaran yang dituangkan dalam bentuk rencana pelaksanaan pembelajaran (RPP) sesuai dengan kompetensi dasar yang nantinya digunakan selama proses pembelajaran, d) Membentuk kelompok siswa (heterogen) yang masing-masing beranggotakan 5-6 orang, e) Menyusun instrumen tes hasil belajar dan kunci jawaban.

Pelaksanaan, Pada tahap ini dilaksanakan tindakan berupa penerapan model pembelajaran Student Team Achievement Divisions (STAD) dalam proses pembelajaran matematika pada siswa kelas VI dalam materi yang telah dibuat pada tahap perencanaan. Setiap siklus terdiri dari 3 kali pertemuan, dengan 2 kali kegiatan pembelajaran dan 1 kali kegiatan evaluasi. Pelaksanaan pembelajaran berpedoman pada skenario dalam RPP yang telah disiapkan.

Observasi, dilaksanakan selama pelaksanaan tindakan (proses pembelajaran berlangsung) untuk mengetahui kelemahan yang dihadapi dan keunggulan yang diperoleh selama menerapkan model pembelajaran Student Team Achievement Divisions (STAD) ketika diterapkan. Evaluasi dilakukan setelah berakhirnya pelaksanaan tindakan siklus, yaitu dengan memberikan tes kepada siswa untuk mengetahui hasil belajar yang dicapai siswa setelah dilaksanakan pembelajaran.

Refleksi, kegiatan refleksi pada masing-masing siklus digunakan sebagai bahan masukan untuk perbaikan kegiatan pembelajaran pada siklus berikutnya, sehingga peningkatan hasil belajar dapat tercapai. Tahap refleksi ini dilakukan untuk mengkaji hasil belajar siswa yang diperoleh setelah penerapan model pembelajaran Student Team Achievement Divisions (STAD) diterapkan. Refleksi ini dilakukan dengan melihat hambatanhambatan yang dialami dalam pelaksanaan tindakan pada setiap siklus dan factor penyebab hambatan tersebut. Selanjutnya, dicari dan ditetapkan beberapa alternatif tindakan baru yang lebih efektif untuk meningkatkan hasil belajar matematika. Alternatif tindakan ini ditetapkan menjadi tindakan baru sebagai 
tindakan perbaikan pada perencanaan tindakan siklus berikutnya.

Pada tahap ini dilaksanakan tindakan berupa penerapan model pembelajaran Student Team Achievement Divisions (STAD) dalam proses pembelajaran matematika kelas VI dalam materi yang telah dibuat pada tahap perencanaan. Kegiatan yang dilakukan dalam tahap ini adalah melaksanakan skenario pembelajaran dengan menggunakan model pembelajaran Student Team Achievement Divisions (STAD) yang telah direncanakan.

$$
\text { Menurut Trianto }
$$

"Pembelajaran kooperatif tipe STAD ini merupakan salah satu tipe dari model pembelajaran kooperatif dengan menggunakan kelompok-kelompok kecil dengan jumlah anggota tiap kelompok 4-5 orang siswa secara heterogen". Di awali dengan penyampaian tujuan pembelajaran, penyampaian materi, kegiatan kelompok, kuis, dan penghargaan kelompok. Setiap siklus terdiri dari 3 kali pertemuan, dengan 2 kali kegiatan pembelajaran dan 1 kali kegiatan evaluasi.

Metode pengumpulan data yang digunakan dalam penelitian ini adalah tes. Tes sebagai tindakan untuk melihat pencapaian tujuan pembelajaran dan penguasaan peserta didik dalam bentuk hasil belajar yang diperlihatkannya setelah peserta didik menempuh pengalaman belajar. Data hasil belajar matematika peserta didik diambil dengan kegiatan evaluasi/tes yang diberikan pada akhir masing-masing siklus. Skor penilaian untuk pilihan ganda masing-masing skornya 1 dan skor penilaian untuk essay masing-masing skornya 2.

Hasil analisis nilai rata-rata kelas yang diperoleh selanjutnya dikonversikan ke dalam Penilaian Acuan Patokan (PAP) skala lima dengan berpedoman pada kriteria seperti pada tabel berikut ini.

Tabel 1 Penilaian Acuan Patokan (PAP) Skala Lima

\begin{tabular}{|c|c|}
\hline $\begin{array}{c}\text { Rentangan nilai } \\
\text { rata-rata kelas }\end{array}$ & Katagori \\
\hline $90-100$ & Sangat tinggi \\
\hline $80-89$ & Tinggi \\
\hline $65-79$ & Sedang \\
\hline $55-64$ & Rendah \\
\hline $0-54$ & Sangat Rendah \\
\hline
\end{tabular}

(sumber: Agung, 2010)

Kriteria keberhasilan yang ditetapkan dalam penelitian ini adalah nilai rata-rata kelas minimal 80 dalam katagori tinggi.

\section{HASIL DAN PEMBAHASAN Hasil}

Penelitian tindakan kelas ini dilaksanakan sesuai dengan tahap-tahap dan prosedur penelitian yang telah ditetapkan sebelumnya. Penelitian ini dilaksanakan mulai tanggal 11 Oktober 2016 sampai tanggl 26 Oktober 2016. Untuk memperoleh data digunakan metode tes. Data yang diperoleh selanjutnya digunakan untuk menjawab masalah-masalah yang telah dirumuskan dalam penelitian. Berikut ini dipaparkan mengenai hasil penelitian pada siklus I dan siklus II.

Penelitian tindakan kelas ini dilaksanakan di kelas VI SD No. 1 Sading, Kecamatan Mengwi, Kabupaten Badung. Siklus I dibagi menjadi 3 kali pertemuan. Pertemuan pertama adalah untuk membahas luas segibanyak yang merupakan gabungan dari persegi dan persegi panjang. Pertemuan kedua adalah untuk membahas luas segi banyak yang merupakan gabungan dari dua bangun datar segitiga dan jajar genjang. Pertemuan ketiga adalah untuk melaksanakan kegiatan evaluasi akhir siklus dengan menggunakan instrumen tes. Berikut ini dipaparkan deskripsi proses pembelajaran siklus I. Hasil belajar matematika siswa pada siklus I memperoleh nilai rata: 73,79 setelah dilakukan konversi maka nilai rata tersebut berada pada katagori sedang. Jika nilai rata-rata kelas yang telah diperoleh pada siklus I dibandingkan dengan kriteria keberhasilan penelitian yaitu nilai rata-rata kelas minimal 80 dalam katagori tinggi ternyata belum mencapai kriteria keberhasilan, berarti penelitian ini dapat dilanjutkan pada siklus II.

Siklus II merupakan penerapan perencanaan tindakan siklus II yang telah dimodifikasi dari siklus I. Siklus Pelaksanaan siklus II dibagi menjadi tiga kali pertemuan. Pertemuan pertama untuk membahas luas segi banyak yang merupakan gabungan dari layang-layang, belah ketupat dan trapesium. Pertemuan kedua membahas luas segi banyak yang 
merupakan gabungan dari dua bangun datar lingkaran. Pertemuan ketiga adalah untuk melaksanakan kegiatan evaluasi akhir siklus.

Pelaksanaan siklus II pada penelitian ini dilaksanakan dalam 3 kali petemuan pertama dan kedua untuk melaksanakan tindakan pembelajaran. Pertemuan pertama hari Rabu, 19 Oktober 2016 dan pertemuan kedua dilaksanakan hari selasa, 25 Oktober 2016. Sedangkan tes hasil belajar setelah Penerapan model pembelajaran Student Team Achievement Divisions (STAD) pada siklus ini dilaksanakan pada hari Rabu, 26 Oktober 2016.

Hasil belajar matematika siswa pada siklus II memperoleh nilai rata : 83,20, setelah dilakukan konversi maka nilai rata tersebut berada pada kategori tinggi. Jika nilai rata-rata kelas yang telah diperoleh pada siklus II dibandingkan dengan kriteria keberhasilan penelitian yaitu nilai rata-rata kelas minimal 80 dalam katagori tinggi ternyata sudah memenuhi kriteria keberhasilan, berarti penelitian ini dapat dihentikan.

\section{Pembahasan}

Berdasarkan permasalahan yang telah dipaparkan pada latar belakang penelitian ini, maka diadakan penelitian tindakan kelas dengan menerapkan model pembelajaran kooperatif tipe Student Team Achievement Divisions (STAD) dalam pembelajaran matematika kelas VI semester I, SD No. 1 Sading kecamatan Mengwi, Kabupaten Badung Tahun Pelajaran 2016/2017. Penelitian ini bertujuan untuk mengetahui peningkatan hasil belajar Matematika pada siswa kelas VI semester ganjil SD No. 1 Sading tahun pelajaran 2016/2017 setelah diterapkannya model pembelajaran kooperatif tipe Student Team Achievement Divisions (STAD). Setelah dilaksanakan penelitian yang berlangsung dalam dua siklus, diperoleh bahwa terjadi peningkatan hasil belajar matematika pada siswa kelas VI semester ganjil SD No. 1 Sading pada tahun pelajaran 2016/2017 setelah diterapkan model pembelajaran kooperatif tipe Student Team Achievement Divisions (STAD). Peningkatan hasil belajar matematika dapat dilihat dari perolehan nilai matematika setelah penelitian dilaksanakan. Adapun hasil belajar matematika berupa nilai dapat dijelaskan sebagai berikut :1) Dari pra siklus ke siklus I .Nilai rata-rata kelas pra siklus 61,9 dengan katagori rendah meningkat pada siklus I sebesar 73,9 dengan katagori sedang. 2) Dari Siklus I ke siklus II. Nilai rata-rata kelas siklus I 73,9 dengan katagori sedang meningkat pada siklus II sebesar 83,2 dengan katagori tinggi.

Maka dapat dilihat peningkatan secara keseluruhan tindakan pembelajaran matematika pada penelitian ini bila dibandingkan sebelum tindakan (pra siklus) sampai pada tindakan siklus II. Dengan demikian maka Penerapan model pembelajaran kooperatif tipe Student Team Achievement Divisions (STAD) dalam pembelajaran matematika kelas VI semester I SD No. 1 Sading kecamatan Mengwi, Kabupaten Badung Tahun Pelajaran 2016/2017 mengalami peningkatan, hal ini terjadi karena materi matematika sangat menarik bagi siswa sehingga siswa antusias dan termotivasi mengikuti pembelajaran. Peningkatan rata-rata dari pra siklus hingga siklus II dapat terjadi karena beberapa hal yaitu Pertama, pembelajaran yang menerapkan model pembelajaran kooperatif tipe Student Team Achievement Divisions (STAD) dapat mengubah pembelajaran yang awalnya berpusat pada guru menjadi pembelajaran yang berpusat pada siswa. Siswa akan menjadi lebih aktif dan mampu membangun pengetahuannya dalam belajar secara berkelompok. Dimana dalam belajar secara berkelompok siswa dapat bertukar pikiran satu sama lainnya; Kedua, pemberian kuis secara individu pada akhir pembelajaran dapat memacu peserta didik belajar lebih antusias agar mereka dapat menjawab soal dengan baik dan mendapat nilai yang baik pula; Ketiga, pemberian reward kepada tim yang berani menyampaikan hasil diskusi kelompoknya dengan benar dan tidak ragu-ragu ke depan kelas. Pemberian reward bertujuan agar anak lebih bersemangat dan meningkatkan partisipasi siswa dalam proses pembelajaran. Melalui partisipasi siswa yang tinggi dalam kegiatan pembelajaran menyebabkan motivasi belajar siswa meningkat, sehingga hasil belajar siswa menjadi optimal. 


\begin{abstract}
Adapaun peningkatan hasil belajar siswa setelah diterapkan model pembelajaran kooperatif tipe Student Team Achievement Divisions (STAD)
\end{abstract} Sejalan dengan pendapat Taniredja, Tukirman (2011) dan Arsana (2012), "Model pembelajaran koperatif tipe STAD merupakan pendekatan cooperative learning yang menekankan pada aktivitas dan interaksi diantara siswa untuk saling memotivasi dan saling membantu dalam menguasai materi pelajaran guna mencapai prestasi yang maksimal". Disamping itu, siswa dimungkinkan mengungkap ide atau pendapatnya dalam diskusi kelompok sehingga siswa akan terlibat aktif dalam pembelajaran dan diharapkan suasana belajar akan lebih bermakna. Djamarah (2005) menyatakan bahwa sebagai motivator, guru hendaknya dapat mendorong siswa menjadi lebih bergairah dan aktif dalam belajar. Selanjutnya Jaelani (2011) menyatakan bahwa adanya motivasi yang baik dalam belajar akan menunjukkan hasil yang baik pula. Dengan adanya usaha yang tekun dan didasari motivasi yang baik, maka siswa dapat mencapai tujuannya dengan hasil belajar yang optimal.

Berdasarkan uraian di atas, penelitian ini secara umum telah mampu menjawab rumusan masalah. Hal ini berarti bahwa penelitian ini telah mampu memecahkan permasalahan rendahnya hasil belajar matematika siswa kelas VI semester I SD No 1 Sading Kecamatan Mengwi, Kabupaten Badung tahun pelajaran 2016/2017. Pada akhir penelitian semua kriteria keberhasilan penelitian telah terpenuhi. Dengan kata lain, penelitian tindakan kelas (PTK) yang telah dilaksanakan telah berhasil.

\section{PENUTUP}

Berdasarkan hasil penelitian dan pembahasan yang telah diuraikan, dapat disimpulkan bahwa hasil belajar Matematika siswa kelas VI semester I SD No. 1 Sading Kecamatan Mengwi, Kabupaten Badung Tahun Pelajaran 2016/2017 dapat meningkat melalui penerapan model pembelajaran kooperatif tipe Student Team Achievement Divisions (STAD). Hal ini dapat dilihat dari semakin meningkatnya nilai rata-rata siswa (M). Pada data awal (prasiklus), rata-rata nilai siswa (M) hanya mencapai 61,9 dengan tingkat hasil belajar yang berada pada kategori rendah. Pada siklus I, rata-rata nilai siswa (M) mengalami peningkatan menjadi 73,9 dengan tingkat hasil belajar yang berada pada kategori sedang, kemudian pada siklus II, rata-rata nilai siswa (M) meningkat menjadi 83,2 dengan tingkat hasil belajar yang berada pada kategori tinggi.

Berdasarkan temuan-temuan dalam penelitian ini dapat diajukan saransaran sebagai berikut. 1) Bagi siswa, hendaknya memepertahankan dan meningkat cara belajar yang baik, dengan disiplin yang tinggi terutama dalam mendengarkan penjelasan guru tetang materi pelajaran dan pada saat mengikuti diskusi kerlompok. 2) Bagi guru, pembelajaran dengan model pembelajaran kooperatif tipe Student Team Achievement Divisions (STAD) dapat memberikan suatu alternatif yang dapat digunakan untuk melaksanakan kegiatan pembelajaran matematika sehingga pembelajaran yang dilaksanakan lebih bervariatif dan tidak monoton seperti yang telah dilaksanakan sebelumnya. 3) Bagi sekolah, disarankan agar hasil penelitian ini dapat dijadikan dasar pijakan dalam mengelola kegiatan pembelajaran sehingga lebih efektif, yang pada akhirnya dapat meningkatkan kualitas dan hasil pembelajaran itu sendiri pada sekolah yang bersangkutan. 4) Bagi peneliti lain, disarankan untuk mengadakan penelitian sejenis pada kelas yang lain sehingga dapat diketahui efektivitas penggunaan model pembelajaran kooperatif tipe Student Team Achievement Divisions (STAD) dalam pembelajaran matematika.

\section{DAFTAR RUJUKAN}

Adesanjaya. 2011

Pembelajaran Kooperatif Tipe STAD. Tersedia pada

http://edutaka.blogspot.co.id/2015/03 /pembelajaran-kooperatif-tipestad.html (diakses tgl 23 September 2016 jam 10.32 wita)

Agung, A.A.Gede. 2010. Metodelogi Penelitian Pendidikan. Fakultas IImu

Pendidikan.Universitas ganesha

Arikunto, Suharsimi, dkk. 2016. Penelitian Tindakan Kelas. Jakarta: PT Bumi Aksara

Arsana, Weda. 2012. Penerapan Pendekatan Konsep 10M Dalam 
Pembelajaran Matematika Untuk Meningkatkan Aktifitas dan Hasil Belajar Matematika Siswa Kelas V SD Raj Yamuna Denpasar Tahun Pelajaran 2011/2012.

Djamarah, Syaiful Bahri.2005.Guru dan Anak Didik dalam Interaksi Edukatif. Jakarta: Rineka Cipta

Ibrahim, M, dkk. 2000. Pembelajaran Kooperatif. Surabaya: University Press

Isjoni. 2012. Cooperatif Learning Mengembangkan Kemampuan Belajar Kelompok. Bandung: Alfabeta

Jaeleni. 2011. Teori Motivasi Belajar. Jakarta:Rajawali Press

Kuntjojo. 2009. Model Pembelajaran Kooperatif. Tersedia pada http://ebekunt.wordpress.com/2009/ 07/31/untitled/ (diakses tanggal 5 Oktober 2016).

Nur, Mohamad. 2005. Pembelajaran Kooperatif. Surabaya: Allyn and Bacon

Nurhadi, dkk. 2004. Pembelajaran Kontekstual dan Penerapannya dalam KBK. Surabaya: Universitas Negeri Malang.

Permen Nomor 16 Tahun 2007 tentang Standar Kualifikasi Akademik dan Kompetensi Guru

Rusman. 2012. Model-Model Pembelajaran. Jakarta: PT Raja Grafindo

Santyasa, Wayan. 2007. Model-Model Pembelajaran Inovatif. Makalah disajikan dalam pelatihan tentang Penelitian Tindakan Kelas bagi Guru-Guru SMP dan SMA di Nusa Penida, Nusa Penida 29 Juni s.d 1 Juli 2007.

Slavin, Robert E. 2008. Cooperative Learning (Teori, Riset dan Praktik). Bandung: Nusa Media.

Soedjadi, R. 2008. Kiat Pendidikan Matematika Di Indonesia. Jakarta: Direktorat Jendral Pendidikan Tinggi Departemen Pendidikan Nasional

Suprijono, Agus. 2009. Cooperative Learning (Teori \& Aplikasi PAIKEM). Yogyakarta:Pustaka Palajar

Taniredja, Tukirman, dkk. 2012. ModelModel Pembelajaran Inovatif. Bandung:Alfabeta
Trianto. 2009. Mendesain Model Pembelajaran Inofatif-Progresif. Jakarta:Kencana

-----. 2011. Penelitian Tindakan Kelas (Classroom Action Research). Jakarta: Prestasi Pustaka Raya

Undang-Undang RI Nomor 20 Tahun 2003 Tentang Sistem Pendidikan Nasional. jakarta: Sinar Grafika 